\title{
Operation Tesla
}

Try to blend in.

\section{Jeff Hecht}

An hour ago, Frankel had been on the holovision stage, being introduced as part of Team Beta.

"It is 200 years since the birth of Nikola Tesla in 1856," the announcer had said. "Now Enigmas of the Twentieth Century is sending three teams of intrepid time travellers to find the legendary inventor's lost papers on wireless transmission, death rays and energy before they went missing."

Now Frankel was back in Tesla's Manhattan, walking north on Sixth Avenue from 40th Street towards the entrance to Bryant Park. Massive yellow taxis zoomed by. A blue-uniformed policeman checked him out, then walked on past, but Frankel still worried. "I haven't heard from Watkins," he said to the phone transmitter buried in his collar.

He could hear Johnson's annoyance through his earpiece. "I told you dead spots are inevitable, even with the main transceiver in the Empire State Building. I know these phones are outdated for 2056, but they're hidden so nobody can see them. Everything you're wearing belongs in October 1937."

"Okay," Frankel agreed, reluctantly. He was grateful the rules let them use technology from any time in the twentieth century. It would have been hard to hide mobile phones built with vacuum tubes. Getting the colours of women's fashions would have been hard, but the three men on Team Beta could get by with dark suits, ties and white shirts. Yet that hadn't helped all-male Team Alpha, who hadn't come back on time.

"Do you see Tesla yet?" Johnson's voice hissed through the earpiece. "He should be near the public library, feeding the pigeons."

Inside the park, Frankel looked east toward the library. A tall, gaunt elderly man on a bench scattered crumbs to a flock of head-bobbing pigeons. Frankel recognized the inventor. He wondered what secrets of power-beaming and wireless transmission were hidden in the missing papers. "I see him. Where's Watkins? I haven't heard from him in 15 minutes."
“That's when he went into the Hotel New Yorker. I watched him from Cut Rate Drugs across Eighth Avenue; I'm having a soda inside. The hotel is a complex 43storey building, and something inside must be blocking his signal. I'll tell him you've spotted Tesla. If I can't reach him on his mobile, I'll head up to Tesla's room myself. I have a set of tools to get in."

"But what if I can't reach you?" Frankel worried. The operation depended on everyone keeping in touch so they could copy the papers and bring them to the retrieval point. They'd lose points if they had to be retrieved from different locations.

"Don't worry. You're perfectly safe. Nobody can eavesdrop on these calls. Just watch Tesla."

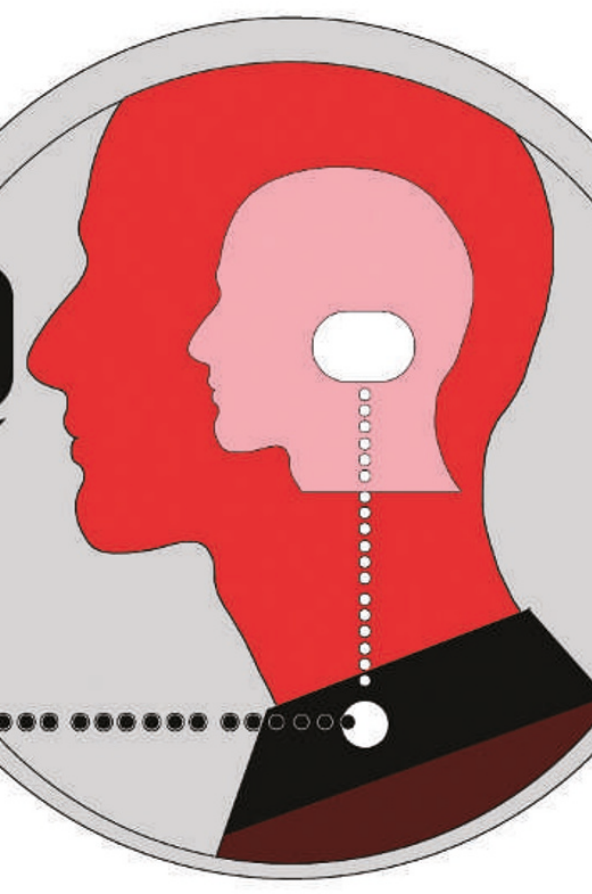

“OK," Frankel agreed. Watching him was the easiest part of the operation. The goal of Operation Tesla was to bring back copies of Tesla's missing papers: Enigmas of the Twentieth Century promised fame and a handsome reward for the team that came back with the best. Watkins and Johnson thought the documents were in the hotel room where he lived. The old-fashioned mechanical locks should be easy to pick; the challenge was to find and copy the right papers.

Frankel settled down on a bench to keep a discreet eye on Tesla. The inventor was engrossed in his pigeons, as if he knew each one. Frankel opened a copy of the New York Sun he had bought from a news vendor. The headlines ranged from world politics to sports. Roosevelt had talked on the transatlantic radio-telephone with the British Prime Minister Neville Chamberlain about Adolf Hitler's meeting with Benito Mussolini. Police were questioning the staff of Bellevue Hospital about three lunatics who had vanished without trace from a locked ward. The Yankees had just beat the New York Giants four games to one in the World Series, and a sports writer wondered how long Lou Gehrig could keep playing.

Glancing at his authentic 1930s watch, Frankel saw it was time for another report. He scanned the park, and noted the inventor feeding the pigeons and three policemen walking down the path that went by him. "Tesla is still feeding the pigeons," Frankel said to his collar.

Nobody replied. That was odd. "Johnson! Watkins! Are you there?" Worried that the police might have caught Watkins and Johnson trying to break into Tesla's hotel room, Frankel tried to look inconspicuous behind his paper. "Johnson, Watkins? Where are you? Rendezvous is in one hour and 15 minutes!"

A heavy hand clamped down on Frankel's right shoulder, and as he started to jump, a second clamped on his left. "All right, pal, we'll take you back to a nice, quiet padded cell," said one of the three policemen suddenly stand-

ing around him. They pulled away his newspaper and snapped handcuffs around his wrists, then patted him down, pulling out his wallet but not spotting the little transmitter sewn into his jacket.

"Johnson, Watkins, help!" He cried into his collar.

The first policeman shook his head. "If those are your pals from Bellevue, they're already at the precinct, talking to themselves - just like you."

Frankel shivered. "They caught Team Alpha, and now they've got me," he said into his collar phone. "I don't know what tipped them off."

The policeman rolled his eyes. Jeff Hecht writes regularly for New Scientist and Laser Focus World. His most recent book is Beam: The Race to Make the Laser. He still uses a landline phone. 